\title{
Research Paper \\ Sugarbeet response to planting methods and dates of sowing in deccan plateau of peninsular India
}

\section{GARISH H. DESHPANDE, B.T. NADAGOUDA AND C.S. HUNSHAL}

See end of the paper for authors' affiliations

Correspondence to :

HARISH H.

DESHPANDE

Faculty of Agriculture,

Water and Land

Management Institute

(WALMI), Kanchanwadi, AURANGABAD (M.S.) INDIA

Email: tnauharish@gmail.

com

\section{Paper History :}

Received : 06.05.2014;

Revised : 13.01 .2015

Accepted : 30.01 .2015
ABSTRACT : An experiment was conducted at Agricultural Research Station, Mudhol, Bagalkot district (Karnataka) to investigate the effect of planting methods and dates of sowing on growth, yield and quality of tropical sugarbeet. The experiment was laid out in Strip Plot Design with five replications. Two planting methods were assigned to horizontal plots viz., $\mathrm{P}_{1}$ : Ridges and furrows $\left(75 \mathrm{~cm}\right.$ apart) and $\mathrm{P}_{2}$ : Broad bed and furrows (6090-60 $\mathrm{cm}$ paired rows). Four dates of sowing were assigned to vertical plots such as August $1^{\text {st }}$ fortnight (FN), September $1^{\text {st }} \mathrm{FN}$, October $1^{\text {st }} \mathrm{FN}$ and November $1^{\text {st }} \mathrm{FN}$. The results revealed that planting sugarbeet in October $1^{\text {st }} \mathrm{FN}$ on broad bed and furrows $(\mathrm{BBF})$ produced significantly higher LAI, total dry matter production and root yield $\left(55.15 \mathrm{tha}^{-1}\right)$. August $\mathrm{1}^{\text {st }} \mathrm{FN}$ sowing produced poor quality beets than the rest of the sowing date treatments.

KEY WORDS : Tropical sugarbeet, Planting methods, Dates of sowing

HOW TO CITE THIS PAPER : Deshpande, Harish H., Nadagouda, B.T. and Hunshal, C.S. (2015). Sugarbeet response to planting methods and dates of sowing in deccan plateau of peninsular India. Internat. Res. J. Agric. Eco. \& Stat., 6 (1) : $83-88$ 